\author{
Case Study
}

\title{
PANCHAKARMA THERAPY IN THE MANAGEMENT OF SYSTEMIC LUPOUS ERYTHEMATOSUS -A CASE REPORT
}

\section{Chinju Thankachan"*, T. K. Sujan², Ambili Krishna ${ }^{3}$}

*1PG Scholar, ${ }^{2}$ Professor \& HOD, ${ }^{3}$ Assistant Professor, Department of Panchakarma, Govt. Ayurveda College, Thiruvananthapuram, Kerala, India.

\begin{tabular}{|c|c|}
\hline Article info & BSTRACT \\
\hline $\begin{array}{l}\text { Article History: } \\
\text { Received: } 27-11-2021 \\
\text { Revised: } 09-12-2021 \\
\text { Accepted: } 23-12-2021 \\
\end{array}$ & $\begin{array}{l}\text { SLE is an autoimmune disorder which can affect the joints, skin, kidney, blood cells, brain, } \\
\text { heart and lungs. In this disease the immune system attacks its own tissues and produces } \\
\text { various symptoms like fatigue, joint pain, rash, fever etc. Symptoms may vary in persons } \\
\text { and can periodically get worse and then improve. }\end{array}$ \\
\hline $\begin{array}{l}\text { KEYWORDS: } \\
\text { Systemic Lupous } \\
\text { Erythematosus, } \\
\text { Gambheera } \\
\text { vataraktha, } \\
\text { Panchakarma } \\
\text { therapy. }\end{array}$ & $\begin{array}{l}\text { Treatment of SLE mainly focuses on controlling the symptoms and therapy improving the } \\
\text { quality of life as there is no complete cure. Medications such as anti-inflammatory and } \\
\text { steroids can be given. In Ayurveda, the symptoms of SLE are more similar to the Lakshanas } \\
\text { of Gambheera vatarakta. Samana oushadhies along with Panchakarma procedures is very } \\
\text { effective in the management of SLE. Successful functional management of SLE with proper } \\
\text { Samana oushadhies and Panchakarma procedures are discussed in this paper. } \\
19 \text { year old male patient with anti ds DNA positive is treated with Samana oushadhies and } \\
\text { given for } 90 \text { days Panchakarma therapy including Vamana, Virechana, Nasya, Nirooha vasthi } \\
\text { and Anuvasana vasthi. The treatment protocol found effective in controlling the progressive } \\
\text { symptoms and improving the functional ability of the patient. There is no complication or } \\
\text { side effects recorded during the entire treatment period. }\end{array}$ \\
\hline
\end{tabular}

\section{INTRODUCTION}

Systemic Lupous Erythematosus is an autoimmune disease in which organs and cells undergo damage initially mediated by tissue binding autoantibodies and immune complexes. In most patients, autoantibodies are present for a few years before the first clinical symptom appears. ${ }^{[1]}$ Interaction between susceptibility genes and environmental factors result in abnormal immune responses, which vary among different patients.

The diagnosis of SLE is based on characteristic clinical features and auto antibodies. The diagnostic criteria for Systemic Lupous Erythematosus includes malar rash, discoid rash, photosensitivity, oral ulcers, arthritis, serositis, renal disorder, neurologic disorder, haematologic disorder, immunologic disorder and antinuclear antibodies.

\begin{tabular}{|l|l|}
\hline \multicolumn{3}{|c|}{ Access this article online } \\
\hline Quick Response Code & \begin{tabular}{l} 
https://doi.org/10.47070/ijapr.v9i12.2220 \\
\hline
\end{tabular} \\
\cline { 2 - 2 }
\end{tabular}

SLE may involve one or several organ systems, over time additional manifestations may occur.

There is no cure for SLE and complete sustained remissions are rare. Therefore the physician should plan to induce improvement of acute flares and then maintain improvements with strategies that suppress symptoms to an acceptable level and prevent organ damage. Among patients with fatigue, pain and autoantibodies of SLE, but without major organ involvement, management can be directed to suppression of symptoms. Analgesics and antimalarials are mainstays. NSAIDS are useful analgesics /anti-inflammatories particularly for arthritis/ arthralgias.

In Ayurveda, SLE can be compared with Gambheera vatarakta, as the symptoms of Gambheera vatarakta is more similar to the common symptoms of SLE.[2] Vataraktha is a disease which is caused by the vitiation of both Vata and Rakta due to different etiological factors. Vata vitiating Ahara and Vihara causes Margavarodha of Vata by Dushita rakta and resulting in the manifestation of Vatarakta. Based on the location, Vataraktha is of two types: Uthana vataraktha and Gambheera vatarktha. In Uthana type, 
the disease affects only in superficial tissues and produce symptoms like skin disease and joint pain. As the condition worsen, it will leads to Gambheera vatarakta which affect blood and other deeper tissues like bone and other joints. This is more complicated stage presented with systemic illness and joint pathology. The main Dosha is Vata and Dooshyas are Rasa, Rakta, Mamsa and Twak. Various Panchakarma proceures and internal medicines are found effective for this condition. $\left.{ }^{3]}\right][4]$

\section{Presenting Complaints}

19 year old male presented with multiple joint pain associated with swelling, tenderness over all major and minor joints, difficulty to move and general malaise. Blood report shows Antids DNA positive, $\mathrm{Hb}$ 9.3g/dl, ESR- $119 \mathrm{~mm} / \mathrm{hr}$, ASO 338, CRP -77 \& VIT D317.3. He took allopathic and homeo treatment and got slight relief.

\section{General Examination}

- Pulse Rate: 105/min., regular, full volume, normal tension.

- Heart Rate: $108 / \mathrm{min}$.

- Respiratory Rate: $22 / \mathrm{min}$.

- Blood Pressure: $120 / 80 \mathrm{mmHg}$

\section{Treatment Protocol}

Samana Oushadhis

\begin{tabular}{|c|l|c|l|}
\hline S.No & Name of the medicine & Dose & Time \\
\hline 1 & Rasnadasamoola kashayam & $15 \mathrm{ml}$ & 6 am \& 6 pm before food \\
\hline 2 & Shaddharanam gulika & $1-0-1$ & After food \\
\hline 3 & Simhanada guggulu & $1-1-1$ & After food \\
\hline 4 & Kaivisha pariharee gulika & $1 / 4-0-0$ & Before food \\
\hline 5 & Sidhamakaradhwajam & $0-0-1$ & After food \\
\hline 6 & Gomutra hareethaki & $15 \mathrm{gm}$ & Two times after food \\
\hline
\end{tabular}

Panchakarma Therapy

\begin{tabular}{|c|c|c|c|c|}
\hline S.no & Procedure & Drug & No. of days & Result \\
\hline 1. & Rookshanam & & & \\
\hline a. & Valuka sweda & & 7 days & Swelling reduced \\
\hline b. & Kadi kizhi & $\begin{array}{l}\text { Kottamchukkadi choornam + } \\
\text { Grihadhoomadi choornam }\end{array}$ & 7 days & Swelling reduced \\
\hline $\mathrm{c}$ & Kashaya dhara & $\begin{array}{l}\text { Dasamoola kashayam + } \\
\text { Punarnavadi kashayam + } \\
\text { Kokilaksham kashayam }\end{array}$ & 7 days & $\begin{array}{l}\text { Pain slightly reduced } \\
\text { Normal appetite }\end{array}$ \\
\hline $\mathrm{d}$ & Avikizhi & $\begin{array}{l}\text { Kottamchukkadi choornam + } \\
\text { Jadamayadi choornam }\end{array}$ & & Weakness reduced \\
\hline 2. & Snehapanam & Shadpalam ghritham & 7 days & Same \\
\hline 3 & Vamana & Madanaphalam & & $\begin{array}{l}\text { Pain \& swelling } \\
\text { reduced }\end{array}$ \\
\hline 4 & Virechanam & Nimbamruthadi erandam & & Same \\
\hline 5 & Kala vasti & $\begin{array}{l}\text { - Anuavasanam with } \\
\text { Madhuyashtyadi tailam } \\
\text { - Nirooha vasthi with }\end{array}$ & & $\begin{array}{l}\text { Improvement in } \\
\text { movements. } \\
\text { Pain \& swelling }\end{array}$ \\
\hline
\end{tabular}


Int. J. Ayur. Pharma Research, 2021;9(12):102-104

\begin{tabular}{|c|l|l|l|l|}
\hline & & $\begin{array}{l}\text { Ksheera kashayam- } \\
\text { Panchathikthakam kashayam } \\
\text { Kokilaksham kashayam } \\
\text { Gudoochyadi kashayam }\end{array}$ & reduced \\
\hline 6 & $\begin{array}{l}\text { Abhyangam + } \\
\text { Ksheeradhoomam+ } \\
\text { Nasya }\end{array}$ & $\begin{array}{l}\text { Mukhabhyangam with Mahamasha } \\
\text { Tailam \& Nasyam with } \\
\text { Maharajaprasaranyadi tailam }\end{array}$ & 7 days \\
\hline 7 & $\begin{array}{l}\text { Shashtika shali } \\
\text { pinda sweda }\end{array}$ & 7 days & $\begin{array}{l}\text { Fatigue reduced more } \\
\text { functional ability }\end{array}$ \\
\hline
\end{tabular}

Blood Report

\begin{tabular}{|l|c|c|}
\hline \multicolumn{1}{|c|}{ Values } & Before treatment & After treatment \\
\hline $\mathrm{Hb}$ & 9.3 & 10.3 \\
\hline $\mathrm{ESR}$ & 119 & 88 \\
\hline $\mathrm{ASO}$ & 338 & 286 \\
\hline $\mathrm{CRP}$ & 77 & 48 \\
\hline Vit.D3 & 17.3 & 20.3 \\
\hline
\end{tabular}

\section{DISCUSSION}

As there is no complete cure for SLE, aim of the treatment protocol is to control the progressive symptoms and improve the functional ability of the patient. Here we selected Samana oushadhies along with Panchakarma therapy which help to eliminate the vitiated Dosas from the body. Vamana, Virechana, Nirooha vasthi, Anuvasana vasthi and Nasya with suitable Poorvakarmas and Paschath karmas are found very effective in reducing the signs and symptoms of SLE. Remarkable improvement was noticed in pain, swelling \& stiffness. Blood report also showed changes in the values of $\mathrm{Hb}$, ESR, ASO \&CRP.

\section{CONCLUSION}

SLE is an autoimmune disorder which may affect almost any organ or system. In Ayurveda, we can correlate the symptoms of SLE with Gambheera Vataraktha. Panchakarma therapy is found safe and effective over a period of 90 days. There is no adverse reaction, complication or side effects recorded during the entire treatment period.

\section{REFERENCES}

1. Harrison.T.R, Dan L. Longo, Harrison's principles of Internal Medicine, $18^{\text {th }}$ International edition (2015), Mc Graw Hill Companies, Part 15, Page2723
2. Pt.Bhishagacharya Harishastri Paradkar edited Dr.Anna Moreswar Kunte collated Ashtanga Hridayam of Vagbhata with the commentaries of Sarvanga Sundara of Arunadatta \& Ayurveda Rasayana of Hemadri, Chowkhambha Krishnadas Academy, Nidana Sthana, Chapter 16, Sloka no 10,11, Page No 536

3. Pt.Bhishagacharya Harishastri Paradkar edited Dr.Anna Moreswar Kunte collated Ashtanga Hridayam of Vagbhata with the commentaries of Sarvanga Sundara of Arunadatta \& Ayurveda Rasayana of Hemadri, Chowkhambha Krishnadas Academy, Chikitsa Sthana, Chapter 22, Sloka no 38, Page No731

4. Vaidya Jadavji Trikamji Acharya edited Charaka Samhitha of Agnivesa with the Ayurveda Dipika commentary by Sri. Chakrapanidatta, Chaukhambha Orientalia, Varanasi Chikitsa Sthana, Chapter 29, sloka No 41-46

5. Ashtavaidyan ET Neelakandhan Mooss, Sudeesh Kumar S, Navaneeth Krishnan N, Smina PB,PKS Nair. Classical Ashtavaidyan Ayurvedic Therapy in the Functional Improvement of Patients with Systemic Lupus Erythematosus: Case Study, International Journal of Ayurveda and Pharma Research. 2019; 7(1): 50-53

\section{Cite this article as:}

Chinju Thankachan, T. K. Sujan, Ambili Krishna. Panchakarma Therapy in the Management of Systemic Lupous Erythematosus- A Case Report. International Journal of Ayurveda and Pharma Research. 2021;9(12):102-104. https://doi.org/10.47070/ijapr.v9i12.2220

Source of support: Nil, Conflict of interest: None Declared

\section{*Address for correspondence} Dr. Chinju Thankachan

PG Scholar,

Department of Panchakarma,

Govt. Ayurveda College,

Thiruvananthapuram, Kerala, India.

Email:

chinjuthankachan115@gmail.com

Disclaimer: IJAPR is solely owned by Mahadev Publications - dedicated to publish quality research, while every effort has been taken to verify the accuracy of the content published in our Journal. IJAPR cannot accept any responsibility or liability for the articles content which are published. The views expressed in articles by our contributing authors are not necessarily those of IJAPR editor or editorial board members. 